\title{
Coagulation Tests and Selected Biochemical Analytes in Dairy Cows with Hepatic Lipidosis
}

\section{S. PADILLA-ARELLANES ${ }^{1}$, F. CONSTANTINO-CASAS ${ }^{1}$, L. NÚÑEZ-OCHOA ${ }^{1}$, J. DOUBEK $^{2}$, C. VEGA-MURGUIA ${ }^{3}$, J. BOUDA $^{1}$}

\author{
${ }^{1}$ Departmento de Patología, Sección de Patología Clínica, Facultad de Medicina Veterinaria y Zootecnia, \\ Universidad Nacional Autónoma de México, México \\ ${ }^{2}$ University of Veterinary and Pharmaceutical Sciences, Faculty of Veterinary Medicine, Brno, Czech Republic \\ ${ }^{3}$ Instituto Nacional de Investigaciones Forestales, Agrícolas y Pecuarias, \\ Ciudad de México, México
}

Received January 30, 2007

Accepted October 2, 2007

\begin{abstract}
Padilla-Arellanes S., F. Constantino-Casas, L. Núñez-Ochoa, J. Doubek, C. VegaMurguia, J. Bouda: Coagulation Tests and Selected Biochemical Analytes in Dairy Cows with Hepatic Lipidosis. Acta Vet. Brno 2007, 76: 541-546.

The aim of this study was to determine the values and changes in conventional and optimised clotting tests, as well as in selected biochemical analytes during hepatic lipidosis in postpartum dairy cows. Ten healthy and ten Holstein cows with hepatic lipidosis were selected based upon clinical history, clinical examination, liver biopsy, flotation test and histological analysis of hepatic tissue. Prothrombin time (PT) and partial thromboplastin time (PTT) were determined in non-diluted and diluted blood plasma samples. Clotting times determined in diluted plasma samples were prolonged in cows with hepatic lipidosis and there was a difference in the PT value at both $50 \%$ and $25 \%$ plasma dilutions between both groups of animals $(P=0.004$ and $P$ $=0.001)$. Significant differences between healthy animals and cows with hepatic lipidosis were observed in blood serum values for free fatty acids (FFA), aspartate aminotransferase (AST) and triacyglycerols $(P=0.001, P=0.007$ and $P=0.044)$, respectively. FFA and liver biopsy are better diagnostic indicators for hepatic lipidosis than coagulation tests. The optimised PT is prolonged in cows with hepatic lipidosis and can detect this alteration that cannot be appreciated using conventional PT test.
\end{abstract}

Haematology, serum biochemistry, fatty liver, cow

Numerous tests are available for the evaluation of coagulation. However, prothrombin time (PT) and partial thromboplastin time (PTT) are the most frequently used tests by clinicians since they are efficient and relatively inexpensive (Palmer 1984). The majority of the proteins that act in the clotting cascade are synthesized by the liver. Therefore when hepatic damage is present, decreased protein synthesis is possible (Troy 1988). Albumin determination is a good indicator of liver function since it is only synthesized by the hepatocytes. However, clotting proteins have a shorter plasma half-life than albumin and can therefore be an early indicator of liver failure (Sutherland 1989).

Prothrombin time (PT) and partial thromboplastin time (PTT) can be altered in animals with liver disease. However, the sensitivity of these tests can be increased when dilutions of the plasma sample (optimised clotting tests) are used (Badylak and van Vleet 1981; Badylak et al. 1983). High yield dairy cows frequently encounter situations of negative energy balance during the first postpartum weeks (Herdt 1988, 2000). This favours the removal of lipids from fatty tissue, which later tends to accumulate in hepatocytes through various mechanisms, thus producing hepatic lipidosis (Gaal et al. 1983; Herdt 2000; Pechová et al. 2002; Bobe et al. 2004). This is the most common cause of liver failure in high yield dairy cows (Cebra et al. 1997; Breukink and Wensing 1997; Pechová et al. 
1997). The determination of optimised PT and PTT can help detect liver failure problems in their initial stages, thus favouring a more prompt diagnosis, timely treatment and a better prognosis for those animals that suffer from hepatic lipidosis. There are no reports in the literature on optimised clotting test values in cattle.

The aim of this study was to determine the values and changes in conventional and optimised clotting tests, as well as those of selected biochemical analytes during hepatic lipidosis in postpartum dairy cows.

\section{Materials and Methods}

Twenty Holstein cows between 5 and 20 days postpartum from two commercial dairy herds in the valley of central Mexico were selected based upon their clinical history, clinical examination, body condition, liver biopsy and flotation test of hepatic tissue in copper sulphate solutions with various densities (Herdt et al. 1983a). These 20 selected cows were divided into Group 1 (healthy, $\mathrm{n}=10$ ), and a Group 2 (presenting hepatic lipidosis, $\mathrm{n}=10$ ). Body condition was determined using the 1 to 5 scale described by Herdt (1988).

Blood was drawn from the caudal vein into tubes containing EDTA (Vacutainer ${ }^{\circledR}$ ) for haemogram, and into plain tubes (Vacutainer ${ }^{\circledR}$ ) for serum biochemical analysis. Serum was harvested by centrifugation at $1000 \mathrm{~g}$ during $10 \mathrm{~min}$ within two hours of collection. For clotting tests, $4.5 \mathrm{ml}$ of blood were drawn into tubes containing sodium citrate $3.8 \%$ (Vacutainer ${ }^{\sqrt{ }}$ ) and plasma was separated within the first hour of collection by centrifugation at $800 \mathrm{~g}$ during $15 \mathrm{~min}$.

After blood sampling, a liver biopsy was carried out, following aseptic techniques, from the eleventh right intercostal space, $20 \mathrm{~cm}$ below the dorsal spine, directing the needle towards the front limbs (Dirksen 1979). To corroborate the diagnosis of hepatic lipidosis, a histological analysis of the liver samples was carried out.

Clotting tests were carried out within six hours of blood collection. PT and PTT were determined in total plasma $(100 \%)$ and in two subsequent dilutions using sterile isotonic $\mathrm{NaCl}$ solution (SIS). In the first dilution (1: 1), $200 \mu \mathrm{l}$ of plasma and $200 \mu \mathrm{l}$ of SIS were used to obtain the concentration of clotting factors at $50 \%$ with respect to total plasma. In the second dilution $(1: 3), 100 \mu 1$ of plasma and $300 \mu 1$ of SIS were used to obtain the concentration of clotting factors at $25 \%$ with respect to total plasma. Clotting test determinations were carried out using semi-automated equipment (Thrombotimer-1, Organon Teknika ${ }^{\circledR}$, Germany). The values of PT and PTT determined in diluted blood plasma samples correspond to optimised clotting tests.

Undiluted plasma samples and the plasma dilutions previously mentioned were utilized to determine PT, using a commercial reagent (rabbit cerebral thromboplastin) following the manufacturer's instructions. The same reagent lot number was used for the entire study. The reaction was started by adding $200 \mu 1$ of the preheated $\left(37^{\circ} \mathrm{C}\right.$ ) commercial reagent and $100 \mu \mathrm{l}$ of plasma, which had been incubated previously for one min at $37^{\circ} \mathrm{C}$.

Undiluted plasma samples and the previously mentioned plasma dilutions were utilized to determine PTT, using a commercial reagent (activated Thrombofax) and following the manufacturer's instructions. The same reagent lot number was used for the entire study. A $100 \mu \mathrm{l}$ volume of plasma and $100 \mu \mathrm{l}$ volume of activating solution were mixed and incubated for two min at $37^{\circ} \mathrm{C}$. The reaction was started using $100 \mu 1$ of calcium chloride $(0.2 \mathrm{~mol} / \mathrm{l})$ that had been incubated previously at $37^{\circ} \mathrm{C}$.

The following serum biochemical analytes were determined using spectrophotometry (Cobas-Mira, Roche ${ }^{\circledR}$, Switzerland) and a $37^{\circ} \mathrm{C}$ incubation: free fatty acids (FFA), aspartate aminotransferase (AST), gamma-glutamyl transferase (GGT), total protein, albumin, urea, total bilirubin, triacylglycerols and creatine kinase (CK). Determinations were made within eight hours of collection, with the exception of the FFA, which were maintained for a maximum of three months at $-20{ }^{\circ} \mathrm{C}$ until testing.

The haemogram was carried out using automated equipment (Cell Dyn 3500R, Abbot Laboratories ${ }^{\circledR}$ ) that determined haemoglobin, packed cell volume (PCV), erythrocyte count, total leukocyte and platelet count. The differential leukocyte count was determined employing the manual method upon a Wright stained blood smear (Knoll 2000).

Liver tissue samples were placed in $10 \%$ buffered formaldehyde $(\mathrm{pH} 7.4)$ for routine histological processing and staining with haematoxylin-eosin $(\mathrm{H}-\mathrm{E})$, as well as Sudan staining for confirmation of hepatic lipidosis. The $\mathrm{H}$-E sections were analysed using a light microscope at $\times 400$; five fields were viewed from the centrilobular to periportal zones evaluating hepatocyte damage and confirming presence of lipids in the Sudan stained sections. A modified technique (Biourge et al. 1994) was used to classify the hepatic damage as follows: Grade 0 - defined or non-defined vacuoles in less than $25 \%$ of the hepatocytes; Grade 1 or slight - non-defined vacuoles in 25 to $50 \%$ of the hepatocytes or lipid vacuoles in 25 to $50 \%$ of the hepatocytes, comprised primarily by microvesicles; Grade 2 or moderate - variable quantity of non-defined vacuoles in the hepatocytes or lipid vacuoles in 50 to $75 \%$ of the hepatocytes, comprised primarily by microvesicles, some macrovacuoles and occasional eccentric nuclei; Grade 3 or severe - variable quantity of non-defined vacuoles in the hepatocytes or lipid vacuoles in more than $75 \%$ of the hepatocytes, both micro- and macrovacuoles, as well as a high number of eccentric nuclei and loss of hepatic architecture.

Student's $t$ test was used to evaluate the significant differences between both groups for the clotting tests, serum biochemistry and haemogram. Repeated-measures analysis of variance was used to study the effect of the 
healthy-ill variable on clotting times using Bonferroni's $t$ test and thus detect differences between dilutions. The SAS (1990) software programme was used for all statistical analyses.

\section{Results}

The cows included in the Group 1 did not have any clinical signs of illness, 7 to $14 \mathrm{~d}$ before parturition an average BCS was 3.5 (3.2 to 3.7); 5 - $20 \mathrm{~d}$ after parturition had an average body condition score of 3.2 (2.8 to 3.5), and normal results in both the liver tissue flotation test with copper sulphate solutions and in the histological analysis. The cows from Group 2 (hepatic lipidosis) 7 to $15 \mathrm{~d}$ before parturition were over-conditioned, BCS an average 3.95 (3.8 to 4.3). After parturition feed intake and milk production were reduced in Group 2, BCS 7 to $20 \mathrm{~d}$ after parturition was 2.2 (1.8 to 2.5). In the flotation test, five of ten cows had liver tissue that floated in a solution of copper sulphate with a 1.055 density, which is classified as light lipidosis, while the other five had liver tissue that floated in both the 1.055 and 1.025 density solutions, considered as moderate lipidosis. The histological analysis for the Group 2 showed seven to be in grade 2 (moderate lipidosis), while the remaining three were classified as grade 3 (severe lipidosis).

Table 1. Values of blood coagulation tests in healthy dairy cows and cows with hepatic lipidosis

\begin{tabular}{|l|c|c|c|c|}
\hline \multirow{2}{*}{ Analyte } & \multirow{2}{*}{$\begin{array}{c}\text { Plasma } \\
\text { dilution }\end{array}$} & $\begin{array}{c}|c| \\
\text { Healthy }(\mathrm{n}=10) \\
\text { Mean } \pm \text { SD (s) }\end{array}$ & $\begin{array}{c}\text { Hepatic lipidosis (n = 10) } \\
\text { Mean } \pm \text { SD (s) }\end{array}$ & Probability \\
\cline { 3 - 5 } & $100 \%$ & $16.5 \pm 1.3$ & $18.1 \pm 2.7$ & $P=0.118$ \\
\hline PT & $50 \%$ & $17.0 \pm 1.4$ & $21.9 \pm 4.5$ & $P=0.004$ \\
\hline PT & $25 \%$ & $20.4 \pm 1.8$ & $29.2 \pm 7.1$ & $P=0.001$ \\
\hline PTT & $100 \%$ & $29.9 \pm 4.2$ & $32.9 \pm 4.9$ & $P=0.167$ \\
\hline PTT & $50 \%$ & $47.7 \pm 8.3$ & $51.2 \pm 9.1$ & $P=0.471$ \\
\hline
\end{tabular}

PT - prothrombin time; PTT - partial thromboplastin time; SD - standard deviation; s - second

The mean values, for the clotting tests increased upon plasma dilution, are shown in Table 1. The mean PT values at non-diluted plasma (100\%) were not significantly different $(P=0.118)$ between Group 1 and Group 2, respectively $(16.5$; range 14.7 to $18.2 \mathrm{~s}$ versus 18.1 ; range (15.4 to $24.3 \mathrm{~s})$. However, repeated-measures analysis of variance for the healthy - ill variable effect on clotting time when using the 50 and $25 \%$ dilutions showed a significant $(P=0.004$ and $P=0.001$, respectively) difference between the means for both groups. Bonferroni's $t$ test detected a significant $(P<0.05)$ difference between the different dilutions (Table 2).

Table 2. Differences between dilutions in coagulation test times of healthy cows and cows with hepatic lipidosis

\begin{tabular}{|l|c|c|}
\hline \multirow{2}{*}{$\begin{array}{c}\text { Analyte } \\
\text { and plasma dilutions }\end{array}$} & \multicolumn{2}{|c|}{ Cows } \\
\cline { 2 - 3 } & $\begin{array}{c}\text { Healthy }(\mathrm{n}=10) \\
(\mathrm{n}=10) \text { Mean } \pm \text { SD }(\mathrm{s})\end{array}$ & $\begin{array}{c}\text { Hepatic lipidosis (n }=10) \\
\text { Mean } \pm \text { SD }(\mathrm{s})\end{array}$ \\
\hline PT $100 \%$ to $50 \%$ & $0.48 \pm 0.32$ & $3.78 \pm 2.63$ \\
\hline PT $50 \%$ to $25 \%$ & $3.40 \pm 0.93$ & $7.27 \pm 3.20$ \\
\hline PT $100 \%$ to $25 \%$ & $3.88 \pm 1.03$ & $11.05 \pm 4.95$ \\
\hline PTT $100 \%$ to $50 \%$ & $17.84 \pm 8.63$ & $18.23 \pm 8.17$ \\
\hline
\end{tabular}

PT - prothrombin time; PTT - partial thromboplastin time; SD - standard deviation; s - second

The mean PTT values at plasma $(100 \%)$ were not significantly $(P=0.167)$ different (29.9 and 32.9 s, respectively) for Group 1 and Group 2. Mean PTT values at plasma diluted $(50 \%)$ were not significantly $(P=0.471)$ different between the groups either. The 
PTT values for the $25 \%$ dilution could not be evaluated since the majority of the samples did not clot upon analysis, or the equipment lacked stability in detecting the clot.

Table 3. Biochemical values in blood serum of healthy dairy cows and cows with hepatic lipidosis

\begin{tabular}{|l|c|c|c|}
\hline \multirow{2}{*}{\multicolumn{1}{|c|}{ Analyte }} & \multicolumn{2}{|c|}{ Cows } & \multirow{2}{*}{ Probability } \\
\cline { 2 - 4 } & $\begin{array}{c}\text { Healthy }(\mathrm{n}=10) \\
\text { Mean } \pm \text { SD }\end{array}$ & $\begin{array}{c}\text { Hepatic lipidosis }(\mathrm{n}=10) \\
\text { Mean } \pm \text { SD }\end{array}$ & $P=0.001$ \\
\hline FFA $(\mathrm{mmol} / \mathrm{l})$ & $0.31 \pm 0.08$ & $0.94 \pm 0.45$ & $P=0.007$ \\
\hline AST $(\mu \mathrm{kat} / \mathrm{l})$ & $1.31 \pm 0.25$ & $2.46 \pm 0.94$ & $P=0.044$ \\
\hline Triacyglycerols $(\mathrm{mmol} / \mathrm{l})$ & $0.12 \pm 0.04$ & $0.15 \pm 0.03$ & $P=0.058$ \\
\hline Bilirubin $(\mu \mathrm{mol} / \mathrm{l})$ & $5.1 \pm 2.5$ & $24.8 \pm 17.7$ & $P=0.105$ \\
\hline Total protein $(\mathrm{g} / \mathrm{l})$ & $69.1 \pm 4.1$ & $75.8 \pm 11.7$ & $P=0.683$ \\
\hline Albumin $(\mathrm{g} / \mathrm{l})$ & $27.8 \pm 3.4$ & $26.8 \pm 6.8$ & $P=0.521$ \\
\hline Urea $(\mathrm{mmol} / \mathrm{l})$ & $4.17 \pm 1.12$ & $3.87 \pm 0.92$ & $P=0.270$ \\
\hline GGT $(\mu \mathrm{kat} / \mathrm{l})$ & $0.30 \pm 0.13$ & $0.30 \pm 0.14$ & \\
\hline
\end{tabular}

FFA - free fatty acids; AST - aspartate amino transferase; GGT - gamma-glutamyl transferase; SD - standard deviation

Table 4. Selected values from haemogram of healthy dairy cows and cows with hepatic lipidosis

\begin{tabular}{|l|c|c|c|}
\hline \multirow{2}{*}{\multicolumn{1}{|c|}{ Analyte }} & \multicolumn{2}{|c|}{ Cows } & \multirow{2}{*}{ Probability } \\
\cline { 2 - 4 } & $\begin{array}{c}\text { Healthy }(\mathrm{n}=10) \\
\text { Mean } \pm \mathrm{SD}\end{array}$ & $\begin{array}{c}\text { Hepatic lipidosis }(\mathrm{n}=10) \\
\text { Mean } \pm \mathrm{SD}\end{array}$ & $P=0.151$ \\
\hline $\mathrm{PCV}(1 / 1)$ & $0.29 \pm 0.02$ & $0.32 \pm 0.07$ & $P=0.172$ \\
\hline $\mathrm{RBC}\left(\times \cdot 10^{12} / 1\right)$ & $5.4 \pm 0.4$ & $6.1 \pm 0.9$ & $P=0.086$ \\
\hline WBC $\left(\times \cdot 10^{9} / 1\right)$ & $7.6 \pm 2.5$ & $10.0 \pm 2.9$ & $P=219$ \\
\hline Platelets $\left.\times \cdot 10^{9} / 1\right)$ & $423 \pm 135$ & $558 \pm 164$ & $P$ \\
\hline
\end{tabular}

PCV - packed cell volume; RBC - red blood cell; WBC - white blood cell; SD - standard deviation

Mean values for serum selected biochemical analytes are shown in Table 3. Significant differences were found between Group 1 and Group 2 for: FFA $(P=0.001)$, AST $(P=0.007)$ and triacylglycerols $(P=0.044)$. Serum concentrations of total bilirubin, total protein, albumin, urea, CK and GGT activity between the Group 1 and Group 2 did not show significant differences. Mean values for haemogram (PCV, haemoglobin, plasma proteins, erythrocyte, total leukocyte and differential count, platelet count) were not significantly different between Group 1 and Group 2 (Table 4).

\section{Discussion}

There is little information concerning clotting tests in cattle. However, the use of these tests is mandatory when one suspects disseminated intravascular coagulation, sweet clover intoxication, liver disease or congenital coagulation disorders (Grubbs and Olchowy 1997).

In our study the values of PT (14.7 to $18.2 \mathrm{~s}$ ) in healthy cows were lower than values (20.1 to $30.1 \mathrm{~s}$ ) described by Heuwieser et al. (1989). In the case of PTT, values for healthy cows had the same tendency ( 18.5 to $40.5 \mathrm{~s}$ and 25.3 to $44.5 \mathrm{~s}$, respectively). The discrepancies between the values found in this study and those reported by other authors (Heuwieser et al. 1989; Prater 2000) could be caused by the differences in equipment and reagents, used for the clotting tests. Due to this, it is recommended that each laboratory obtain its own reference values in accordance with their work conditions.

To our knowledge, there are no published data on optimised clotting tests in dairy cows. 
In the present study, we found significant differences in PT at plasma dilution $50 \%$ and $25 \%$ between healthy cows and those with hepatic lipidosis. However, there were no significant differences in the PTT tests at $100 \%$ or $50 \%$. Alterations in hepatic synthesis of clotting factors can be analogous to hepatic albumin synthesis. Albumin is only synthesised by the liver, has a longer half-life than clotting factors and its concentration is frequently decreased as a consequence of many hepatic diseases as well as renal and gastrointestinal disorders (Latimer et al. 2003). PT and PTT values are well correlated with alterations in plasmatic albumin concentration (Badylak et al. 1983). Therefore, a decrease in the synthesis of other proteins produced in the liver, such as clotting factors, could have produced the increase in PT and PTT observed in this study. This study on dairy cows did not find significant differences in albumin values for both groups. The changes in values of PT can be due to the decrease in clotting factors synthesis and to their shorter half-life in comparison with albumin.

It has been mentioned that the FFA are increased in cows with hepatic lipidosis (Gaal et al. 1983; Herdt 1988; Jorritsma et al. 2003; Lubojacká et al. 2005) which is in agreement with our study. FFA are therefore considered to be of great importance in the diagnosis of hepatic lipidosis. Serum activity of hepatic enzymes is not a sensitive indicator of hepatic lipidosis in cattle. However, AST has been the only enzyme that has shown to have some correlation with hepatic lipidosis in this species (Herdt 1988). In this study we observed an increase in AST activity and statistically significant differences between cows with hepatic lipidosis and healthy ones. Cows with hepatic lipidosis have low concentrations of triacylglycerols (Herdt et al. 1983a; Pechova et al. 1997), as was observed in this study, but significant difference was found between Groups 1 and 2. This could be associated with the impeded release of very low-density lipoproteins that was observed in hepatic lipidosis (Herdt et al. 1983a).

Hepatic lipidosis is associated with a negative energy balance causing rapid mobilization of peripheral fat reserves and the rapid development of the condition since the cow's liver has very little capacity to export excess lipids in the form of lipoproteins (Cebra et al. 1997; Herdt et al. 1983b). The histological analysis in this study confirmed the hepatic lipidosis that had been diagnosed by flotation tests. Sudan staining is necessary to confirm the H-E staining, since, in the latter technique, lipidosis can be confused with hydropic degeneration and glycogen deposition, producing a microvacuole appearance (King and Alroy 1997).

It is concluded that clotting times are prolonged in dairy cows with hepatic lipidosis due to decreased hepatic synthesis of clotting factors. FFA, AST together with liver biopsy are better diagnostic indicators for hepatic lipidosis than coagulation tests. As mentioned previously, the optimised PT test can detect changes that cannot be appreciated with conventional PT technique.

\section{Koagulační testy a vybrané biochemické hodnoty u dojnic s jaterní steatózou}

Cílem práce bylo stanovit hodnoty a změny v rutinně a optimalizovaně stanovených koagulačních testech a ve vybraných biochemických analytech u dojnic s jaterní steatózou. Deset zdravých dojnic a deset s jaterní steatózou plemene Holstein bylo vybráno na základě anamnézy, klinického vyšetrení, jaterní biopsie, flotačních testů a histologického vyšetrení jaterní tkáně. Protrombinový čas (PČ) a aktivovaný parciální tromboplastinový čas (aPTC̆) byly stanoveny v neředěných a ředěných vzorcích krevní plazmy. Koagulační časy stanovené v ředené plazmě (optimalizovaný test) byly prodloužené u dojnic s jaterní steatózou; rozdíly byly zjištěny v hodnotách PČ v plazmě ředěné $50 \%$ a $25 \%$ mezi dojnicemi zdravými a dojnicemi s jaterní steatózou $(P=0.004$ a $P=0.001)$. Signifikantní rozdíly mezi zdravými zviŕaty a dojnicemi s jaterní steatózou byly nalezeny v hodnotách krevního séra pro volné mastné kyseliny (VMK), AST a triacylglyceroly $(P=0.001, P=0.007$ 
a $P=0.044)$. VMK a analýzy jaterních bioptátů jsou lepšími diagnostickými ukazateli pro jaterní steatózu než koagulační testy. Optimalizovaný PČ byl prodloužen u dojnic s jaterní steatózou a může detekovat tuto alteraci, která není určena při použití rutinního stanovení PČ.

\section{Aknowledgments}

This study was funded by the Research Project of Universidad Nacional Autónoma de México, PAPIIT IN 213106-3.

\section{References}

BADYLAK SF, DODDS WJ VAN VLEET JF 1983: Plasma coagulation factor abnormalities in dogs with naturally occurring hepatic disease. Am J Vet Res 44: 2336-2340

BADYLAK SF, VAN VLEET JF 1981: Alterations of prothrombin time and activated partial thromboplastin time in dogs with hepatic disease. Am J Vet Res 42: 2053-2056

BIOURGE VC, GROFF JM, MUNN RJ, KIRK CA, MADEIROS VA, MORRIS JG, ROGERS QR 1994: Experimental induction of hepatic lipidosis in cats. Am J Vet Res 55: 1291-1302

BOBE G, YOUNG JW, BEITZ DC 2004: Invited review: Pathology, etiology, prevention, and treatment of fatty liver in dairy cows. J Dairy Sci 87: 3105-3124

BREUKINK HJ WENSING T 1997: Pathophysiology of the liver in high yielding dairy cows and its consequences for health and production. Israel J Vet Med 52: 66-72

CEBRA CK, GARRY FB, GETZY DM, FETTMAN MJ 1997: Hepatic lipidosis in anorectic, lactating Holstein cattle: A retrospective study of serum biochemical abnormalities. J Vet Intern Med 11: 231-237

DIRKSEN G 1979: Digestive system. In: ROSENBERGER G (Ed.): Clinical Examination of Cattle. $1^{\text {st }}$ ed. Philadelphia, Saunders W.B, pp. 184-266

GAAL T, ROBERTS CJ, REID IM, DEW AM, COPP CM 1983: Blood composition and liver fat in post parturient dairy cows. Vet Rec 113: 53-54

GRUBBS ST, OLCHOWY TW 1997: Bleeding disorders in cattle: A review and diagnostic approach. Vet Med 97: 737-743

HERDT TH 1988: Fatty liver in dairy cows. Vet Clin North Am Food Anim Pract 4: 269-287

HERDT TH 2000: Ruminant adaptation to negative energy balance. Influences on the etiology of ketosis and fatty liver. Vet Clin North Am Food Anim Pract 16: 215-230

HERDT TH, GOEDERS L, LIESMAN JS, EMERY RS 1983a: Test for estimation of bovine hepatic lipid content. J Am Vet Assoc 182: 953-955

HERDT TH, LIESMAN JS, GERLOFF BJ 1983b: Reduction of serum triacylglycerol-rich lipoprotein concentrations in cows with hepatic lipidosis. Am J Vet Res 44: 293-296

HEUWIESER W, BIESEL M, GRUNET E 1989: Physiological coagulation profile of dairy cattle. Zbl Vet-Med (A) 36: 24-31

JORRITSMA R, GROOT MW, VOS PL, KRUIP TA, WENSING T, NOORDHUIZEN JP 2003: Acute fasting in heifers as a model for assessing the relationship between plasma and follicular fluid NEFA concentrations. Theriogenology 60: 151-161

KING NW, ALROY J 1997: Intracellular and extracellular depositions; degenerations. In: JONES TC, HUNT RD, KING NW (Eds.): Veterinary Pathology. $6^{\text {th }}$ ed. Baltimore, Williams and Wilkins, pp. 25-41

KNOLL JS 2000: Clinical automated haematology systems. In: FELDMAN BF, ZINKL JG, JAIN NC (Eds.): Schalm's Veterinary Haematology. $5^{\text {th }}$ ed. Philadelphia, Lippincott, pp. 3-11

LATIMER KS, MAHAFFEY EA, PRASSE KW 2003: Duncan \& Prasse's Veterinary Laboratory Medicine: Clinical Pathology. $4^{\text {th }}$ ed. Ames, Iowa State Press, $450 \mathrm{p}$.

LUBOJACKÁ V, PECHOVÁ A, DVORÁK R, DRASTICH P, KUMMER V, POUL J 2005: Liver steatosis following supplementation with fat in dairy cows diets. Acta Vet Brno 74: 217-224

PALMER RL 1984: Laboratory diagnosis of bleeding disorders. Postgrad Med 76: 137-148

PECHOVÁ A, ILLEK J, HALOUZKA R 1997: Diagnosis and control of the development of hepatic steatosis in dairy cows in the periparturient period. Acta Vet Brno 66: 235-243

PECHOVÁA, ILLEK J, PAVLATAL 2002: Einwirkungen der Lebersteatose auf den Stoffwechsel bei Milchkuhen. Wien Tierarztl Monatschr 89: 325-332

PRATER MR 2000: Acquired coagulopathy II: Liver disease. In: FELDMAN BF, ZINKL JG, JAIN, NC (Eds.): Schalm's Veterinary Haematology. $5^{\text {th }}$ ed. Philadelphia, Lippincott, pp. 560-564

SUTHERLAND RJ 1989: Biochemical evaluation of hepatobiliary system in dogs and cats. Vet Clin North Am Small Anim Pract 19: 899-927

TROY GC 1988: An overview of haemostasis. Vet Clin North Am Small Anim Pract 18: 5-20

SAS/STAT1990: User's guide: Vol 2 GLM-VARCOMP, Version 6. $4^{\text {th }}$ ed. Cary (NC): SAS Inst Inc. 